\title{
CONSTRUCTS FOR PRODUCTION OF A PROBE FOR MONITORING OF CHS3 EXPRESSION IN SACCHAROMYCES CEREVISIAE
}

\author{
Leona Kafkováa, Vladislav Raclavskýb \\ a Institute of Biology, Faculty of Medicine, Palacký University, CZ-775 15 Olomouc, Czech Republic \\ ${ }^{b}$ Centre of Molecular Biology and Medicine, Faculty of Medicine, Palacký University, CZ-775 15 Olomouc, Czech \\ Republic
}

Received January 19, 2000

Key words: Saccharomyces cerevisiae / Chitin synthesis / CHS3 / Expression

Chitin and $\beta$-1,3-glucan are known to play an important role in determination of fungal cell wall rigidity in Saccharomyces cerevisiae ${ }^{1}$. Three chitin synthases participate in yeast chitin synthesis. ChS1p functions as a reparation enzyme after cell division ${ }^{2}, \mathrm{ChS} 2 \mathrm{p}$ is responsible for the synthesis of primary septum ${ }^{3,4}$ and ChS3p synthesizes chitin in the lateral wall and in the ring at the base of future septum ${ }^{4}$. All of the enzymes are supposed to be cell cycle regulated and expression of CHS3 was described to be strongly reduced in $m p k 1$ mutant $^{5}$. The Mpk1p MAP-kinase is a component of the cell wall integrity and proliferation pathway, known as PKC1-pathway as well. This pathway participates in the regulation of cell cycle progress ${ }^{6,7}$ and in hypotonic shock signalling ${ }^{8}$. Further, chitin synthesis was earlier described to increase markedly in yeast cells exposed to fluorescent brighteners Calcofluor white and Rylux $\mathrm{BSU}^{9,10}$. Chitin synthase 3 gene should be the main target of stimulation in vivo in both Calcofluor white ${ }^{11}$ and Rylux BSU ${ }^{10,12}$. Therefore, CHS3 expression is supposed to be increased in case of plasma membrane stretch. This stretch can be caused by hypotonic shock or weakening of cell wall if harmed by fluorescent brighteners. Kamada et al. ${ }^{13}$ have found activation of Mpk1pkinase in response not only to hypotonic shock, but in response to mild heat shock $\left(37^{\circ} \mathrm{C}\right)$ and in response to chlorpromazine, which inserts into the cytoplasmic leaflet of the plasma membrane lipid bilayer and thus induces an inward membrane stretch. However, we have not found any increase in cell wall chitin content in yeast cells treated with chlorpromazine and have found an decrease in cell wall chitin content in yeast cells grown at $37{ }^{\circ} \mathrm{C}$ (unpublished results). On the other hand, cell wall chitin content was increased in cells grown in hypotonic environment. To clarify the role of CHS3 expression in response to different environmental conditions, we decided to construct a RNA-probe, which would allow us to monitor the expression of CHS3.

\section{MATERIAL AND METHODS}

Probe design. Sequences of CHS3 and ACT1 (as control) were obtained from Saccharomyces Genome Database maintained at Stanford University, School of Medicine. These sequences were searched for recognition sites of restriction endonucleases using the freeware Digest. Sequence segments circumscribed by recognition sites of enzymes suitable for cloning were selected and primers were designed to amplify these regions of interest. Freeware Primer 0.5 was used for primer design, annealing temperature was set to be $56^{\circ} \mathrm{C}$. CHS3 and ACT1 sequences with marked primer sequences and restriction sites are summarised in Fig. 1 and Fig. 2.

DNA isolation. Saccharomyces cerevisiae strain CCY 22-23-1 was grown in YPD (yeast extract 1\%[w/v], peptone $1 \%[\mathrm{w} / \mathrm{v}]$, dextrose $2 \%[\mathrm{w} / \mathrm{v}])$ in a shaking water bath at $30{ }^{\circ} \mathrm{C}$ overnight. Yeast cells were harvested by centrifugation and washed twice in $1 \mathrm{ml}$ of $\mathrm{dH}_{2} \mathrm{O} .200 \mu \mathrm{l}$ of breaking buffer (Triton X-100 2\%[v/v], SDS $1 \%[\mathrm{v} / \mathrm{v}]$, $\mathrm{NaCl} 100 \mathrm{mM}$, TrisCl 10mM, pH 8.0, EDTA 1mM), $200 \mu \mathrm{l}$ of acid washed glass beads $(0.4 \mathrm{~mm}$ in diameter) and $200 \mu \mathrm{l}$ of phenol-chloroform-isoamylalcohol (25:24:1) were added and vortexed at maximum speed for $3 \mathrm{~min}$. Then, $200 \mu \mathrm{l}$ of TE buffer (TrisCl $100 \mathrm{mM}$, pH 7.5, EDTA $1 \mathrm{mM}, \mathrm{pH} 8.0$ ) were added, mixed shortly by vortexing and centrifuged at $12000 \mathrm{~g}$ at laboratory temperature for $5 \mathrm{~min}$. Supernatant was transferred into a clean tube, $4 \mu \mathrm{l}$ of Proteinase $\mathrm{K}(10 \mathrm{mg} / \mathrm{ml})$ were added, mixed and incubated at $37^{\circ} \mathrm{C}$ for $60 \mathrm{~min}$. Then, $68 \mu \mathrm{l}$ of $5 \mathrm{M} \mathrm{NaCl}$ and $54 \mu \mathrm{l}$ of $10 \%$ [w/v] CTAB were added, mixed and incubated at $65^{\circ} \mathrm{C}$ for $15 \mathrm{~min}$. After cooling to laboratory temperature, 1 vol of chloroform-isoamylalcohol (24:1) were added, mixed thoroughly and centrifuged at $12000 \mathrm{~g}$ at laboratory temperature for 5 min. To remove proteins, supernatant was reextracted 1-2 $\times$ using phenol-chloroform-isoamylalcohol (25:24:1) with a final extraction with chloroform-isoamylalcohol. 
$0.6 \mathrm{vol}$ of isopropanol was added to supernatant and mixed carefully by inversion to precipitate nucleic acids. These were centrifuged at $12000 \mathrm{~g}$ at laboratory temperature for $5 \mathrm{~min}$ and washed twice by $70 \%$ [v/v] ethanol. Pellet was resuspended in $400 \mu \mathrm{l}$ of TE buffer. $3 \mu \mathrm{l}$ of RNAse A (20 mg/ml) were added and incubated at $37{ }^{\circ} \mathrm{C}$ for 60 min to remove RNA. $15 \mu$ were loaded on agarose and electrophoresed for control of complete RNA removal. Then, $40 \mu$ of $4 \mathrm{M}$ ammonium acetate and $1 \mathrm{ml}$ of absolute ethanol were added and mixed by inversion to precipitate the DNA. This was pelleted by centrifugation at $12000 \mathrm{~g}$ at laboratory temperature for $5 \mathrm{~min}$, washed once with $70 \%[\mathrm{v} / \mathrm{v}]$ ethanol and resuspended in $400 \mu \mathrm{l}$ of TE buffer. $\mathrm{A}_{260}$ was 1.8 and higher.

PCR reaction. Forward primer CGC TGA AAT GGT TAA AGA TC and reverse primer TTC TTC TTA TGC AAA GTG TTG were used for amplification of a part of the CHS3 gene. Forward primer ATG GTC AAG TCA TCA CTA TTG G and reverse primer CAG ACG GAG TAC TTT CTT TCT $G$ were used for amplification of a part of the ACT1 gene. In both cases, PCR reaction was assembled in $20 \mathrm{ml}$ as follows: template DNA 70ng, dNTPs $200 \mu \mathrm{M}$ each, primers $4 \mu \mathrm{M}$ each and Pfupolymerase 0.6 U. Amplification was performed in 13 cycles of denaturation at $94{ }^{\circ} \mathrm{C}$, annealing temperature decreasing by $1{ }^{\circ} \mathrm{C}$ in each cycle from $67^{\circ} \mathrm{C}$ to $55^{\circ} \mathrm{C}$, and extension at $72^{\circ} \mathrm{C}$, followed by 15 cycles of denaturation at $94{ }^{\circ} \mathrm{C}$, annealing at $54^{\circ} \mathrm{C}$ and extension at $72{ }^{\circ} \mathrm{C}$.

Restriction digestion and purification of fragments. PCR products and plasmid pGEM-4Z were digested using HindIII and KpnI. Digestion reactions were performed in $20 \mu \mathrm{l}$ as follows: DNA $1 \mu \mathrm{g}$, HindIII $5 \mathrm{U}$, KpnI $5 \mathrm{U}$ and $0,1 \mathrm{mg} / \mathrm{ml}$ BSA. The pGEM-4Z-plasmid was purified by phenol/chloroform extraction to remove the small fragments resulting after HindIII/KpnI digestion. ACT1 fragment was purified using electrophoresis in $2 \%$ lowmelting point agarose, and isolated using Wizard PCR Preps DNA purification System (Promega). CHS3 fragment was purified using $4 \%$ low-melting point agarose, and isolated by phenol/chloroform extraction. Briefly, the gel slice was melted at $67^{\circ} \mathrm{C}$ for 10 minutes and TE buffer was added to lower the agarose concentration to less then $0.5 \%$. An equal volume of buffer-equlibrated phenol was added, sample was vortexed for 15 seconds and centrifuged at $12000 \mathrm{~g}$ for 3 minutes. The aqueous phase was reextracted with phenol followed by one extraction with equal volume of phenol/chloroform (1:1) and one extraction with equal volume of chloroform. The aqueous phase was chilled on ice for 15 minutes and centrifuged at $12000 \mathrm{~g}$ and $4{ }^{\circ} \mathrm{C}$ for 15 minutes. The supernatant was carefully transferred into a clean tube and DNA was precipitated by adding ammonium acetate to a final concentration of $0.3 \mathrm{M}$ and 2.5 vol of absolute ethanol. Sample was mixed by inversion and centrifuged at $12000 \mathrm{~g}$ for 5 minutes. The pellet was washed twice with $70 \%$ ethanol a resuspended in $50 \mu \mathrm{l}$ of sterile redistilled water.

Ligation. The linearized pGEM-4Z was processed by CIAP (calf intestinal alkaline phosphatase) to pre- vent formation of plasmid/plasmid constructs during ligation. $0.01 \mathrm{U}$ of CIAP was used per 1 pmol of DNA ends to dephosphorylate protruding 5'-termini in $100 \mu \mathrm{l}$ reaction at $37^{\circ} \mathrm{C}$ for 30 minutes, then, further $0.01 \mathrm{U}$ of CIAP was added and incubated for 30 minutes again. The DNA was purified by phenol/chloroform extraction. Ligation was performed in $10 \mathrm{ml}$ reaction containing vector pGEM-4Z 150ng, inserted fragment $35 \mathrm{ng}$ (1:5 molar ratio of vector and insert DNA), DNA T4 ligase $1 \mathrm{U}$ and incubated overnight at $4{ }^{\circ} \mathrm{C}$.

Transformation of bacteria. Escherichia coli JM109 competent cells were prepared as follows. Cells were grown in SOB medium (proteose peptone $2 \%[\mathrm{w} / \mathrm{v}]$, yeast extract $0.5 \%[\mathrm{w} / \mathrm{v}], \mathrm{NaCl} 10 \mathrm{mM}, \mathrm{KCl} 2.5 \mathrm{mM}$, $\mathrm{MgCl}_{2} 0.1 \mathrm{mM}, \mathrm{MgSO}_{4} 0.1 \mathrm{mM}$ ) at $37^{\circ} \mathrm{C}$ until $4-7 \times 10^{7}$ cells $/ \mathrm{ml}$ concentration. Cells were then chilled on ice for 15 minutes and harvested by centrifugation at $4{ }^{\circ} \mathrm{C}$. Supernatant was removed carefully and cells were resuspended in RF1 solution ( $\mathrm{RbCl} 100 \mathrm{mM}, \mathrm{MnCl}_{2} 50 \mathrm{mM}$, $\mathrm{CH}_{3} \mathrm{COOK} 30 \mathrm{mM}, \mathrm{CaCl}_{2} 10 \mathrm{mM}$, glycerol $15 \%$ [w/v], $\mathrm{pH} 5.8)$ and incubated on ice for 15 minutes. The volume of RF1 used corresponded to $1 / 3$ of the volume of SOB used for cultivation. Cells were harvested by centrifugation at $4{ }^{\circ} \mathrm{C}$ and resuspended in $\mathrm{RF} 2$ solution (MOPS $10 \mathrm{mM}, \mathrm{RbCl} 10 \mathrm{mM}, \mathrm{CaCl}_{2} 75 \mathrm{mM}$, glycerol $15 \%$ [w/v], $\mathrm{pH} 6.8)$ and incubated on ice for $15 \mathrm{~min}$. The volume of RF2 used corresponded to $1 / 12.5$ of the volume of SOB used for cultivation. Competent cells were aliquoted and stored frozen at $-80{ }^{\circ} \mathrm{C}$ until used. For transformation, $200 \mu \mathrm{l}$ of competent cells were melted at laboratory temperature, chilled on ice and $10 \mathrm{ml}$ of ligation mixture (150 ng plasmid DNA) were added and mixed thoroughly. After 60 minutes of incubation on ice cells were heat shocked by transferring the tube to $42{ }^{\circ} \mathrm{C}$ for 90 seconds and chilled on ice again. $800 \mu \mathrm{l}$ of SOC medium (yeast extract $0.5 \%[\mathrm{w} / \mathrm{v}]$, tryptone $2 \%[\mathrm{w} / \mathrm{v}]$, $\mathrm{NaCl} 10 \mathrm{mM}, \mathrm{KCl} 2.5 \mathrm{mM}, \mathrm{MgCl}_{2} 10 \mathrm{mM}, \mathrm{MgSO}_{4} 10$ $\mathrm{mM}$, glucose $20 \mathrm{mM}$ ) were added and incubated at moderate shaking at $37{ }^{\circ} \mathrm{C}$ for 60 minutes. Cells were inoculated on LB plates containing $100 \mu \mathrm{g} / \mathrm{ml}$ of ampicilin, $0.5 \mathrm{mM}$ IPTG and $40 \mu \mathrm{g} / \mathrm{ml} \mathrm{X-gal} \mathrm{for} \mathrm{blue} \mathrm{and}$ white color screening and grown overnight at $37^{\circ} \mathrm{C}$. After 24 hours of cultivation white colonies were transferred to LB with ampicilin, grown to logaritmic phase, plasmid DNA was isolated using DNA Lego kit (Top Bio) and checked for successful insertion and transformation by HindIII/KpnI digestion.

\section{RESULTS}

Results of amplification are summarised in Fig. 3. The lengths of both PCR products correspond with the length as expected in accordance with distance between the annealing sites of primers in the sequences of CHS3 and ACT1. Results of HindIII/KpnI restriction digestion of PCR products are summarised in Fig. 4. Lengths of fragments correspond with the expected lengths in accordance with the position of recognition sequences 
of HindIII and KpnI as found in the sequences of CHS3 and ACT1. Results of restriction digestion of plasmids carrying inserts are summarised in Fig. 5. HindIII/KpnI restriction digestion results in two fragments of expected lengths corresponding with the size of linear pGEM-4Z and CHS3 or ACT1 insert, respectively. To conclude, constructs have been prepared which will allow us to prepare RNA probes using SP6/T7 run-off transcription. These probes will be used for detection of CHS3 and ACT1 mRNA and thus for monitoring of CHS3 expression in Saccharomyces cerevisiae.

\section{ACKNOWLEDGEMENTS}

Leona Kafková was supported by the Internal Grant Agency, Palacký University No. 11201103.

Vladislav Raclavsky was supported by the Ministry for Education, Youth and PT, grants No. VS 96154 and J14/ 98151100001.

\section{REFERENCES}

1. Hartland, R. P., Vermuelen, C. A., Klis, F. M., Sietsma, J. H., Wessels, J. G. H. (1994) The linkage of [1-3]-beta-glucan to chitin during cell wall assembly in Saccharomyces cerevisiae. Yeast, 10, 1591-1599.

2. Cabib, E., Silverman, S. J., Shaw, J. A. (1992) Chitinase and chitin synthase I: counterbalancing activities in cell separation of Saccharomyces cerevisiae. J. Gen. Microbiol., 138, 97-102.

3. Sburlati, A., Cabib, E. (1986) Chitin synthetase 2, a presumptive participant in septum formation in Saccharomyces cerevisiae. J. Biol. Chem., 261, 15147-15152.
4. Shaw, J. A., Mol, P. C., Bowers, B., Silverman, S. J., Valdivieso, M. H., Durán, A., Cabib, E. (1991) The function of chitin synthases 2 and 3 in the Saccharomyces cerevisiae cell cycle. J. Cell. Biol., $114,111-123$

5. Igual, J. C., Johnson, A. L., Johnston, L. H. (1996) Coordinated regulation of gene expression by the cell cycle transcrition factor SWI4 and the protein kinase C MAP kinase pathway for yeast cell integrity. EMBO J., 15, 5001-5013.

6. Levin, D. E., Fields, F. O., Kunisawa, R., Bishop, J. M., Thorner, J. (1990) A candidate protein kinase C gene, PKC1, is required for the Saccharomyces cerevisiae cell cycle. Cell, 62, 213-224.

7. Lee, K. S., Irie, K., Gotoh, Y., Watanabe, Y., Araki, H., Nishida, E., Matsumoto, K., Levin, D. E. (1993) A yeast mitogen-activated protein kinase homolog $(\mathrm{Mpk} 1 \mathrm{p})$ mediates signalling by protein kinase C. Mol. Cell. Biol., 13, 3067-3075.

8. Davenport, K. R., Sohaskey, M., Kamada, Y., Levin, D. E., Gustin, M. C. (1995) A second osmosensing signal transduction pathway in yeast. J. Biol. Chem., 270, 30175-30161.

9. Roncero, C., Durán, A. (1985) Effect of Calcofluor white and Congo red on fungal cell wall morphogenesis: in vivo activation of chitin polymerization. J. Bacteriol., 163, 1180-1185.

10. Haplová, J., Farkaš, V., Hejtmánek, M., Kod’ousek, R., Malínský, J. (1994) Effect of the new fluorescent brightener Rylux BSU on morphology and biosynthesis of cell walls in Saccharomyces cerevisiae. Arch. Microbiol., 161, 340-344.

11. Gaughran, J. P., Lai, M. H., Kirsch, D. R., Silverman, S. J. (1994) Nikkomycin $\mathrm{Z}$ is a specific inhibitor of Saccharomyces cerevisiae chitin synthase isozyme Chs 3 in vitro and iv vivo. J. Bacteriol., 176, 5857-5860.

12. Raclavský, V., Novotný, R., Šmígová, J., Vojkůvka, Z. (1999) Nikkomycin Z counteracts the Rylux BSU and Congo red inhibition of Saccharomyces cerevisiae growth but does not prevent formation of aberrant cell walls. Folia Microbiol., 44, in press.

13. Kamada, Y., Sung-Jung, U., Piotrowski, J., Levin, D. E. (1995) The protein kinase C-activated MAP kinase pathway of Saccharomyces cerevisiae mediates a novel aspect of the heat shock response. Genes and Development, 9, 1559-1571. 

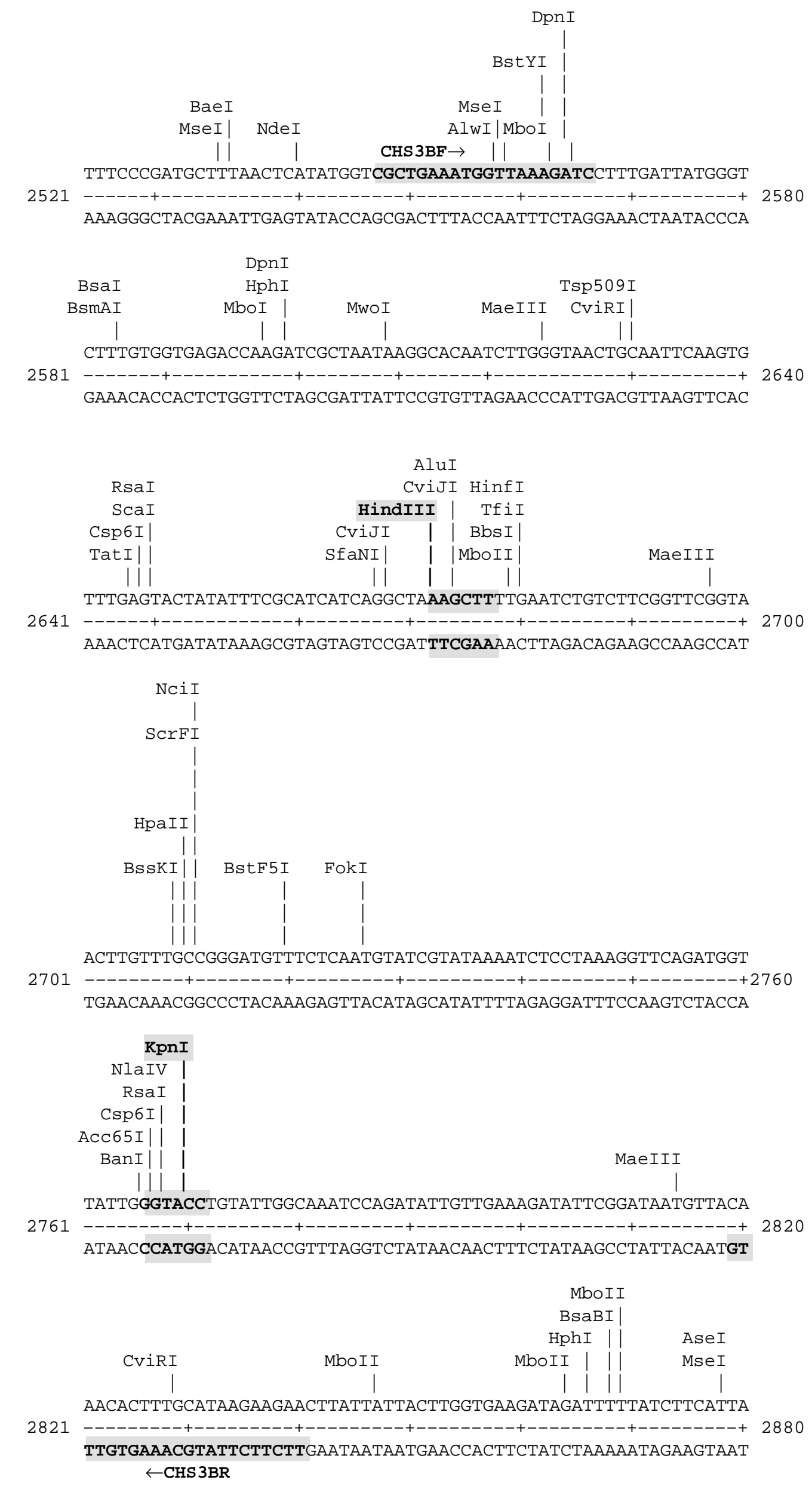

Fig. 1. Part of CHS3 gene with restriction sites and marked primer sequences. 

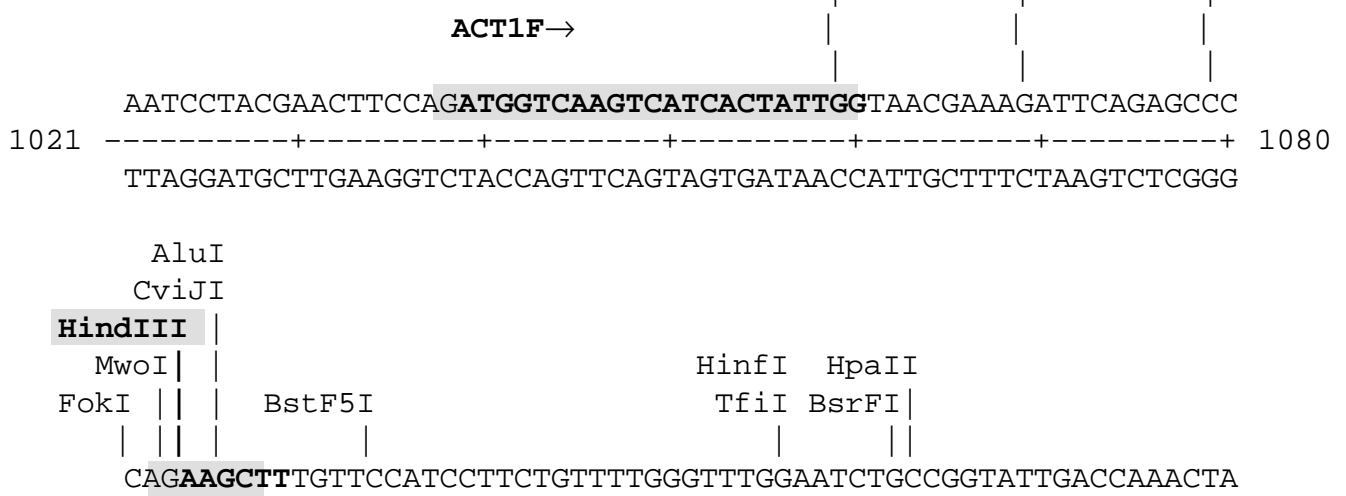

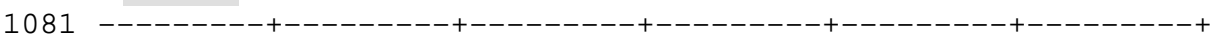

GTCTTCGAAACAAGGTAGGAAGACAAAACCCAAACCTTAGACGGCCATAACTGGTTTGAT

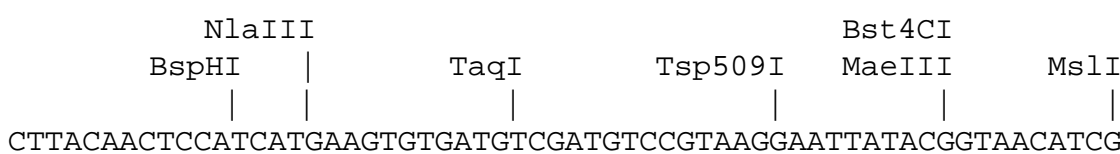

$1141---------+---------+---------+---------+---------+---------+$

GAATGTTGAGGTAGTACTTCACACTACAGCTACAGGCATTCCTTAATATGCCATtGTAGC

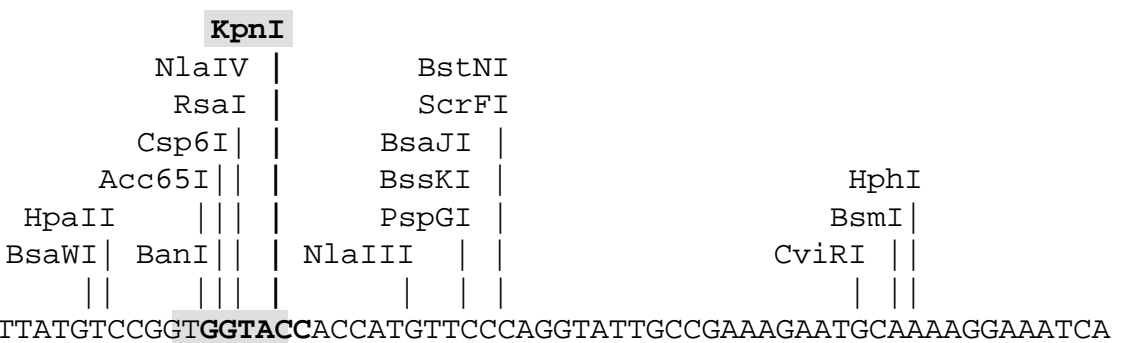

1201

TTATGTCCGGTGGTACCACCATGTTCCCAGGTATTGCCGAAAGAATGCAAAAGGAAATCA

AATACAGGCCACCATGGTGGTACAAGGGTCCATAACGGCTTTCTTACGTTTTCCTTTAGT

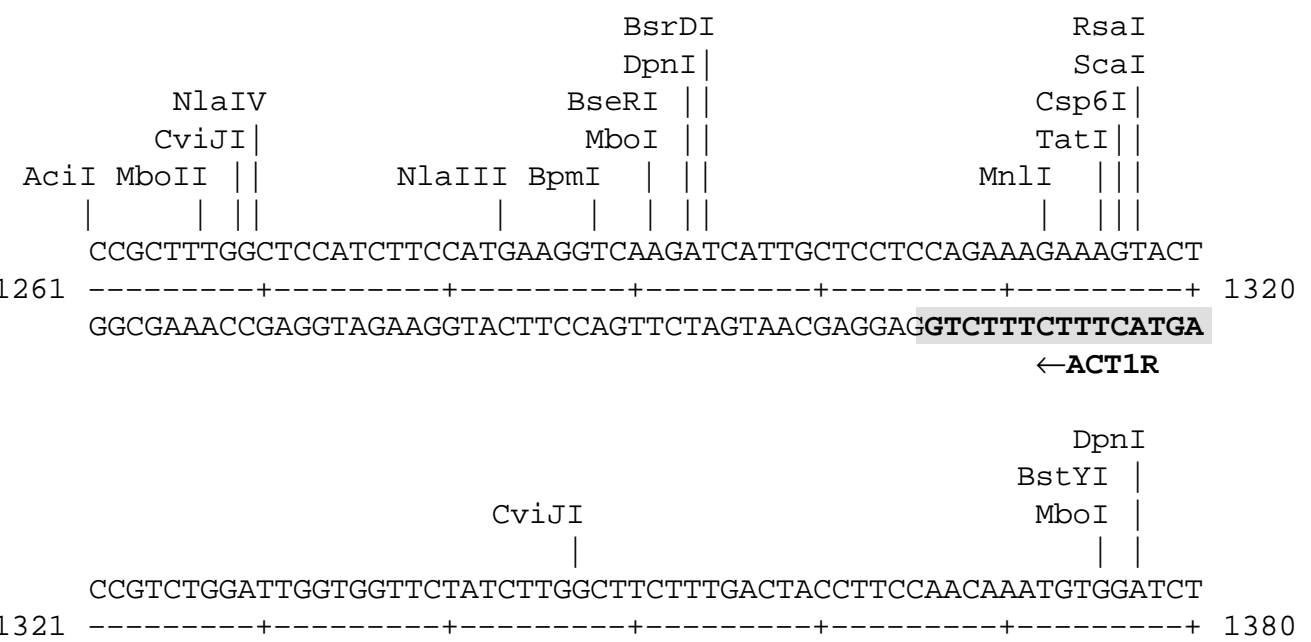

GGCAGACCTAACCACCAAGATAGAACCGAAGAAACTGATGGAAGGTTGTTTACACCTAGA

Fig. 2. Part of ACT1 gene with restriction sites and marked primer sequences. 


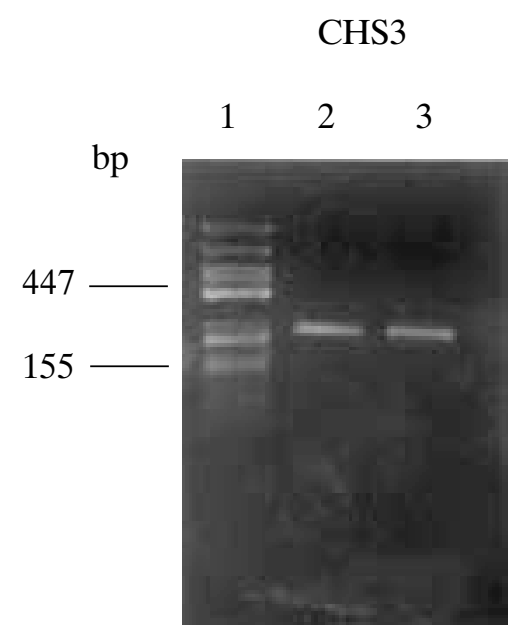

line number:

1. DNA marker $970-155$

2. amplification of CHS3 (294)

3. amplification of CHS3 (294)

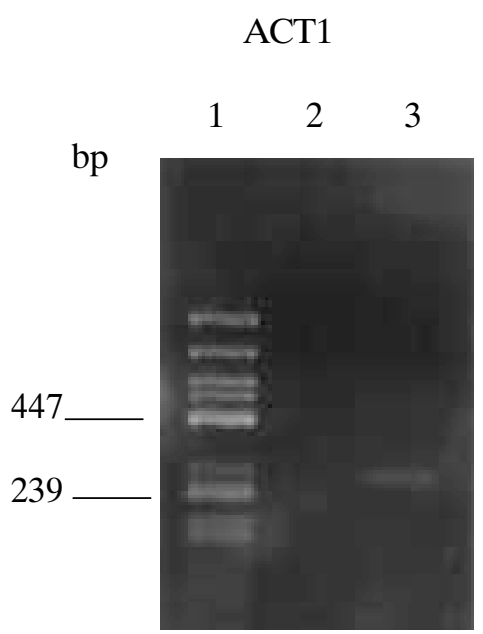

line number:

1. DNA marker $970-155$

2. negative control

3. amplification of ACT1 (289)

Fig. 3. Amplification of CHS3 gene and ACT1 gene.

\section{CHS3}

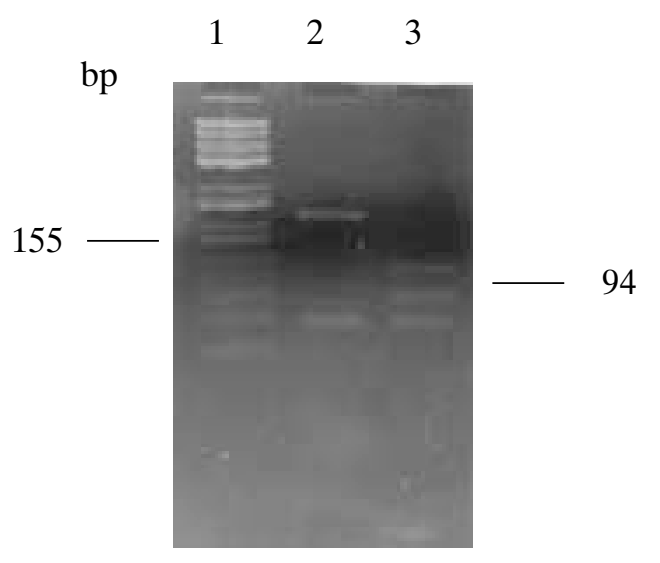

line number:

1. DNA marker 970-155

2. PCR product after restriction digestion with KpnI (225 bp)

3. PCR product after restriction digestion with KpnI and HindIII (94 bp)
ACT1

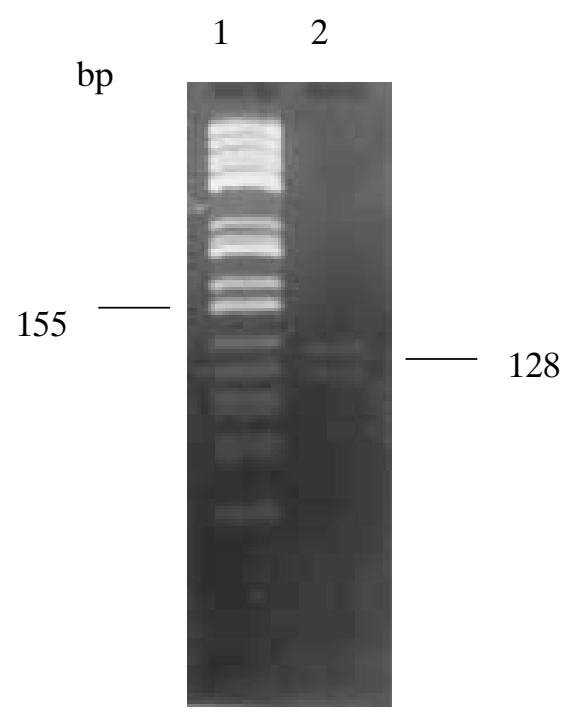

line number:

1. DNA marker $970-155$

2. PCR product after restriction digestion with KpnI and HindIII (128 bp)

Fig. 4. Restriction digestion of PCR products with HindIII/KpnI. 
vector pGEM-4Z + insert CHS3

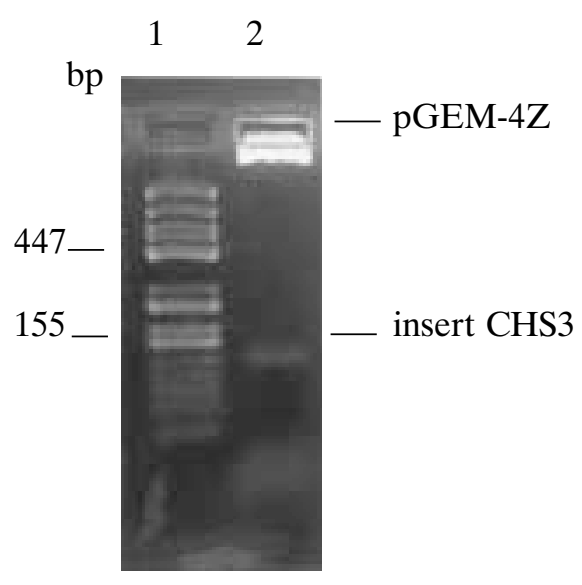

line number:

1. DNA marker $970-155$

2. vector containing cloned insert CHS3 vector pGEM-4Z + insert ACT1

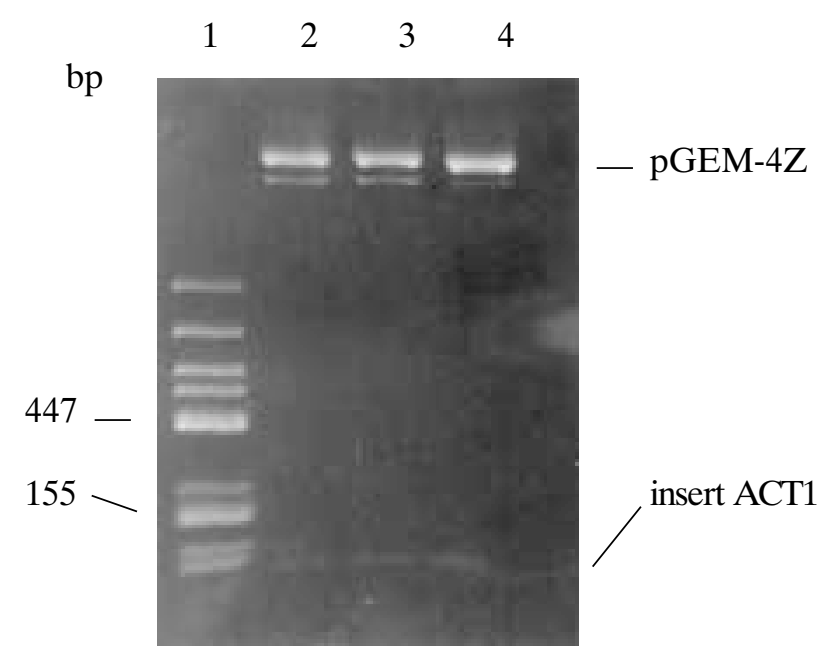

line number:

1. DNA marker $970-155$

2. vector containing cloned insert ACT1

3. vector containing cloned insert ACT1

4. vector containing cloned insert ACT1

Fig. 5. Restriction digestion of plasmids carrying inserts. 